\section{Padanan Terjemahan it ke dalam Bahasa Indonesia dalam novel Harry Potter and The Order of The Phoenix}

Anna Nurawalia*, Tri Mastoyo Jati Kesuma Fakultas IImu Budaya, Universitas Gadjah Mada Surel: annanurawalia011@gmail.com

\title{
INTISARI
}

Kesulitan utama penerjemah adalah menerjemahkan konsep, konteks yang berbeda dari dua bahasa selain pola, fitur-fitur linguistik dan gaya bahasa yang tentu berbeda pula. Quirk (1985) mengklasifikasikan it hanya dalam penggunaan it sebagai anticipatory. Di lain sisi, Bolinger dalam grammar sederhana (1977) menyatakan bahwa kata 'it' adalah kata benda pasti yang memiliki fungsi rujukan tertentu untuk menciptakan wacana yang kohesi dan koherensi. Namun, menurut Halliday (1984) dan Matthiessen (1989), fungsi kata it seharusnya tidak hanya terbatas pada struktur kalimat secara sintaksis. Oleh sebab itu, penelitian ini mengkaji kembali bentuk gramatikal dan makna kata 'it' pada pergeseran padanan terjemahannya ke dalam bahasa Indonesia, faktor-faktor yang menyebabkan terjadinya pergeseran bentuk, kesepadanan makna dan ketidaksejajaran bentuk. Penelitian ini merupakan analisis deskriptif komparatif dengan 500 data berupa kata, frasa dan kalimat dari novel Harry Potter and The Order of The Phoenix, karya J.K Rowling dan terjemahannya dalam TSu (Bahasa Indonesia) dengan metode padan referensial dan padan terjemahan.

Berdasarkan analisisi data, hasil menemukan bahwa kata it yang secara semantis tidak bermakna adalah it yang tidak memiliki rujukan pada TSu terutama ketika membahas mengenai kondisi lingkungan yang mengekspresikan waktu, jarak, dan cuaca merupakan it yang bersifat impersonal dan anticipatory yang paling banyak ditemukan mengalami perubahan gramatikal yang menyebabkan pergeseran bentuk dari TSu ke dalam TSa sebagai akibat dari tipologi bahasa yang berbeda antara TSa dan TSu, dan konsep kata it yang tidak terdapat dalam TSu.

Kata kunci: Kesepadanan, Transformasi Grammatikal, Shifting, Kata 'it' dalam terjemahannya

\section{PENDAHULUAN}

Di dalam proses penerjemahan, ditemukan banyak sekali kata it, hal ini menunjukan bahwa penggunaan dan pemaknaan it terlihat sangat sederhana. Namun, pada kenyataannya, menerjemahkan kata it dengan padanan yang tepat dalam bahasa sasaran cukup rumit. Di dalam traditional modern grammar, menurut Quirck et al. (1985), terdapat tiga jenis it, sebagai berikut Referential it yakni it sebagai rujukan, it sebagai impersonal (tanpa merujuk kepada apapun/siapapun), dan it sebagai anticipatory. it sebagai referential dapat merujuk pada seseorang, sebuah objek atau sesuatu. Impersonal it adalah ketika it sama sekali tidak memiliki makna atau tidak merujuk kepada suatu apapun, dan biasanya digunakan untuk mengekspresikan cuaca, iklim, musim, waktu, jarak, lingkungan, dan lain sebagainya. 
Anticipatory it biasanya ketika it bertindak sebagai formal subjek atau formal objek (selalu dalam bentuk a noun phrase), sementara subjek dan objek yang sesungguhnya akan muncul pada akhir kalimat.

Sementara itu, Quirk (1985) mengklasifikasikan it hanya dalam penggunaan 'it' sebagai anticipatory. Di lain sisi, Bolinger dalam grammar sederhana (1977) menyatakan bahwa kata 'it' adalah kata benda pasti (a definit nominal) yang memiliki fungsi rujukan tertentu untuk menciptakan wacana yang kohesi dan koheren. Namun, menurut Halliday (1984) dan Matthiessen (1989), fungsi kata it seharusnya tidak hanya terbatas pada struktur kalimat secara sintaksis. Oleh sebab itu, penelitian ini merupakan sebuah awal mengkaji kembali secara menyeluruh penggunaan dan arti kata 'it' secara gramatikal pada penerjemahannya ke dalam bahasa Indonesia terutama dengan menggunakan objek kajian kesusasteraan; novel, melihat bentuk-bentuk pergeseran terjemahan it, bentuk-bentuk kesepadanan terjemahan it, dan faktor yang menyebabkan terjadinya pergeseran bentuk, kesepadanan makna, ketidaksepadanan, kesejajaran bentuk dan ketidaksejajaran bentuk.

Mengacu kepada perbedaan antara bentuk struktur kebahasaan pada dua jenis bahasa yang berbeda, seorang penerjemah akan menghadapi kesulitan dalam memindahkan pesan dari bahasa sumber ke bahasa sasaran. Berdasarkan latar belakang di atas, penelitian ini mengkaji beberapa hal yang sangat spesifik terkait dengan terjemahan padanan kata ganti it yang di temukan pada novel Harry Potter; The Order of The Phoenix karya J.K Rowling, di publikasikan di London, New York di tahun 2014 (sebagai Teks Sumber, TSu) dan terjemahannya (sebagai Teks Sasaran, TSa) yang di terjemahkan oleh Listiana Srisanti dan di publikasikan oleh Gramedia Jakarta di tahun 2002. Berikut merupakan salah satu contoh-contoh kasus pada kata it:

Contoh 1:

Bsu: 'Hadn't it been he who had entered that graveyard and watched Cedric being murdered and been tied to that tombstone and nearly killed ... ?' (Hal.3 bab.1)

Bsa: 'Bukankah dirinya yang telah datang di makam dan menyaksikan Cedric di bunuh? Dan bukankah dirinya yang di ikat di nisan dan nyaris terbunuh?' (Hal.19, bab 1).

Di dalam bahasa sumber it merupakan subjek yang menggantikan subjek asli yakni klausa setelahnya sehingga bersifat anticipatory cleft, dan hampa makna. Ketika di terjemahkan, penerjemah memilih it tidak diterjemahkan secara literal, informasi it hilang dalam TSa.

Contoh 2:

BSu: 'Ministry representatives will be calling at your place of residence shortly to destroy your wand. There was only one thing for it' (Hal. 5 bab 2) 
BSa: Petugas kementrian sihir akan datang ke tempat tinggal anda tak lama lagi untuk menghancurkan tongkat sihir anda. Hanya ada satu cara untuk menghindarinya. (Hal.46-47 bab 2)

Di dalam bahasa sumber it bersifat referensial; memiliki rujukan dalam TSu yakni sebuah situasi yang menjelaskan bahwa 'petugas kementrian sihir akan datang ke tempat tinggal Harry tak lama lagi untuk menghancurkan tongkat sihirnya', kemudian it diterjemahkan menjadi -nya dalam bentuk affikasasi di TSa, dan secara literal melekat pada kata kerja 'menghindari', daripada menerjemahkannya menjadi bentuk yang lebih jelas misalnya 'untuk itu', penerjemah memilih mengubah bentuk penerjemahannya menjadi 'menghindarinya'.

Contoh 3:

Bsa: 'We need more height. ... Give it another quarter of a mile!' (Hal. 55, bab3)

Bsu: Kita perlu terbang lebih tinggi... naik empat ratus meter lagi! (Hal.57, Bab 4)

Dalam TSu, it bersifat impersonal, hadir sebagai pemenuhan kaidah gramatikal bahasa Inggris; SVA (Subject Verb Agreement) sehingga it dalam posisi ini tidak memiliki makna semantik dan tidak memiliki rujukan pada TSu. Penerjemah memilih untuk tidak menerjemahkan it secara literal dan mengubah bentuk strukturnya menjadi 'naik empat ratus meter lagi'.

Lebih lanjut, ketiga contoh kasus di atas menunjukan sifat it yang sangat gramatikal membuat penerjemah akan kesulitan dalam menentukan penggunaan it sendiri yang makna semantiknya bisa berubah-ubah sesuai konteks dan co-text dimana it berada, hal ini akan memicu kebingungan bagi penerjemah untuk mencari padanan it ke dalam TSa. Penerjemahan pada akhirnya, tidak hanya menyebabkan perluasan makna dan perubahan bentuk struktur TSA dan TSU tetapi juga pada aspek gramatikal dari it sendiri dan aspek-aspek leksikal tertentu yang memiliki keterikatan kohesi dan koherensi wacana serta mempengaruhi penerjemahan kata it itu sendiri. Hal ini menjadi masalah utama bagi penerjemah dan peneliti untuk memahami dan memindahkan pesan dari TSu ke TSa seakurat mungkin, mengingat karya sastra sulit untuk diterjemahkan.

Pada kenyataannya fenomena transformasi padanan terjemahan yang menyebabkan pergeseran struktur dan makna dari TSU ke TSA bukanlah hal yang asing dalam penerjemahan. Fenomena ini dapat terjadi dalam banyak bentuk. Hal tersebut sesuai dengan yang disampaikan oleh Catford (1985) dan Baker (1992) dalam bukunya masing-masing. Kedua ahli pada bidang terjemahan tersebut mengidentifikasi dan mengelompokan beberapa bentuk pergeseran penerjemahan ke dalam beberapa jenis. Catford menemukan dua tipe pergeseran, yaitu level shift (pergeseran tingkat), dan category shift (pergeseran kategori). Pergeseran kategori dibagi 
menjadi empat jenis pergeseran yang lebih spesifik yakni, structure shift (pergeseran struktur), class shift (pergeseran kelas), unit shift (pergeseran unit), dan intra-system shift (pergeseran intra-sistem).

Suseryo dan Kirana (2016) sebelumnya telah meneliti mengenai "Analisis kata It dalam Novel Windmills of The Gods, karya Sidney Sheldon dan Terjemahannya" (Suatu Kajian Sintaksis dan Semantik), Tujuan penelitianya adalah untuk mengetahui bagaimana kata it diterjemahkan ke dalam bahasa Indonesia, mengetahui faktor-faktor apa saja yang mempengaruhi penerjemahan kata it dan apakah terdapat pergeseran padanan kata it dalam kategori sintaksis dan ditemukan bahwa kata it yang diterjemahkan hanya mengalami pergeseran kelas kata dan unit dan ada tiga kategori penerjemahan kata it. Penelitian ini membahas hal yang sama yakni terjemahan padanan it namun kajian dengan hasil penelitian yang digambarkan hanya membahas mengenai pengkategorian rujukan it ke dalam bahasa sumber dan bahasa sasaran beserta padanan terjemahannya yang kemudian diklasifikasikan lagi berdasarkan kategori pergeseran secara sintaksis.

Peneliti menemukan 500 data it berupa frasa, klausa, kalimat dan dalam bentuk paragraf dengan padanan terjemahannya yang sangat beragam dalam novel "Harry Potter and The Order of The Phoenix", menjadikannya layak untuk ditelaah. Novel ini diterjemahkan sebanyak lebih dari 73 bahasa berbeda dan salah satunya adalah bahasa Indonesia, dan telah terjual sejumlah 450 juta kopi sehingga banyaknya terjemahan ini mengindikasikan kualitas novel yang baik dan secara komoditas dikenal oleh hampir seluruh orang di dunia dan di terima oleh hampir seluruh kalangan. Di mulai dari penelitian mengenai dependent clause, metafora dan gaya bahasa, serta pronomina atau kata ganti menjadikan novel ini adalah salah satu sumber utama untuk diteliti. Terkait dengan novel ini, belum ada penelitian yang mengkaji secara holistik mengenai kata it, pergeseran padanan terjemahannya ke dalam bahasa Indonesia dan faktor penyebab terjadinya pergeseran dalam konvesi bahasa, sehingga penelitian dengan metode deskriptif analisis komparatif ini menjadi sangat krusial untuk ditelaah lebih lanjut oleh penulis.

\section{HASIL DAN PEMBAHASAN}

1. Bentuk-Bentuk Pergeseran Grammatikal Padanan Terjemahan it ke dalam Bahasa Indonesia pada novel Harry Potter and The Order of The Phoenix

\section{a. Pergeseran Kategori}

Pergeseran Struktur 


\section{Data 1}

TSU : It took them most of the afternoon to retrieve their books and belongings from all over the house. (Hal.154 Bab.9)

[[...] mengambil/menghabiskan seluruh sore mereka untuk mengambil buku-buku mereka dan barang-barang dari dalam rumah]

TSA : Mereka menghabiskan sepanjang sore untuk mengambil buku-buku dan barangbarang mereka dari berbagai tempat di rumah. (Hal.239-240 Bab.9)

Pada data (1), klausa tidak dapat diterjemahkan secara sejajar ke dalam bahasa sasaran karena perbedaan pola struktur kalimat ke dua bahasa tersebut. Kata it yang melekat pada klausa tersebut merupakan anticipatory cleft, sementara bahasa sasaran mengenal konsep cleft namun dalam struktur yang berbeda. Pada akhirnya, penerjemah melakukan penghilangan karena tidak ada padanan kata it dalam teks sumber. Kata it pada kalimat cleft tidak memiliki rujukan secara literal karena fungsi it hanya menonjolkan informasi utama atau mewakili tindakan utama dalam kalimat TSU yakni to retrieve their books and belongings....yang di terjemahkan sepadan ke dalam TSA yakni untuk mengambil buku-buku dan barang-barang..." Pada teks sasaran, penerjemah memilih untuk tidak menerjemahkan it yang bisa saja diterjemahkan menjadi hal ini berdasarkan arti literal yang dirujuk pada kamus Oxford yang kemudian menunjukkan bahwa ada kecenderungan penerjemah mementingkan penyampaian pesannya dan bukan untuk mementingkan kesesejaran bentuk antara TSu dan TSa. Pada hasil terjemahannya, bisa diasumsikan bahwa tidak adanya kesesejaran bentuk, akan tetapi tetap memiliki kesepadanan makna. Kesejajaran bentuk tidak terjadi sebagai akibat perbedaan struktur TSU dan TSA.

\section{Data 2}

TSU: It was not easy to hold a wand steady and carry Dudley along the road.

[[...] tidak mudah untuk memegang sebuah tongkat sihir dengan kokoh dan membawa Dudley sepanjang jalan.

TSA: Tak mudah memegangi tongkat sihir dengan mantap dan menyeret Dudley pada saat bersamaan.

Pada data (2) TSU bersifat antisipatory cleft yang pada struktur kalimatnya mengharuskan kehadiran it untuk mengisi fungsi subjek dan untuk menonjolkan infromasi bahwa 'Tak mudah memegangi tongkat sihir,..." Kalimat ini merupakan bentuk cleft, jika di balik maka akan seperti berikut 'To hold a wand steady and carry Dudly along the road was not easy', namun baik dalam bentuk tulisan maupun lisan bahasa Inggris sangat jarang menggunakan struktur seperti ini. Pemfokusan atau penonjolan informasi biasanya di ikuti pemarkah definit 
'ini' dan 'itu' di dalam bahasa sasaran. Oleh sebab itu, it dalam TSU tidak diterjemahkan oleh penerjemah meskipun sebenarnya penerjemah bisa saja menerjemahkan kata it dengan kata tunjuk 'ini' atau 'itu', sebab rujukannya bersifat ektoforis atau berada di luar konteks teks, sehingga seharusnya di rujuk secara ekstralingual. Namun penerjemah memilih menghilangkan informasi kata it dalam TSA sebagai pertimbangan efektifitas atau gaya bahasa pada teks narasi.

Intra Sistem

\section{Data 1}

TSU: It starts at eight o'clock now. (Hal.123 bab 7)

[ [..] mulai pada pukul delapan sekarang]

TSA: Mulainya pukul delapan sekarang. (Hal. 189 bab.7)

Pada data (1) pergeseran terjadi pada tataran gramatikal intra sistem dari bahasa sumber yang mengenal sistem tenses 'it starts...' sedangkan bahasa sasaran mengenal kala dalam bentuk leksikal 'Mulainya...'. Kata it sebenarnya dapat diterjemahkan secara sejajar dengan disubstitusikan ke referensinya. Misal disubtisusi dengan leksikal 'acaranya', sehingga kalimatnya menjadi 'Acaranya mulai...' tetapi untuk efektivitas kalimat, penerjemah mengubahnya menjadi struktur yang berbeda seperti pada TSA. Penerjemah bisa saja menerjemahkannya menjadi sebagai berikut, 'acara ini mulai pukul delapan sekarang', 'acara itu mulai pukul delapan sekarang', acaranya itu mulai pukul delapan sekarang'. Bahasa Indonesia membolehkan demonstratif pronoun seperti 'ini', 'itu', menjadi keterangan tambahan mengikuti nomina induk yang dirujuk atau bersamaan dengan nominanya meskipun tidak mutlak hadir. Kata it dalam hal ini diterjemahkan menjadi sufiks -nya yang melekat pada verba mulai. Kata It bersifat referensial anaforis yang memiliki rujukan pada TSA, merujuk pada konteks sebelumnya.

\section{Data 2}

TSU: Harry felt a dull, sinking sensation in his stomach and, before he knew it.

[Harry merasakan sebuah kebosanan, sensasi perasaan hampa di perutnya, sebelum di tahu [..] ]

TSA: Harry merasakan perutnya tertohok kekecewaan dan sebelum disadarinya.

Pada data (2) menunjukan bahwa pergeseran terjadi pada tataran intra-sistem pada TSA. Kata it mengalami penghilangan (elipsis) - dan bersifat referensial anaforis. Kata it dalam unit klausa 'he knew it' diterjemahkan menjadi leksikal bersufiks -nya yang melekat pada verba disadari. Struktur S-P-O pada TSU diterjemahkan menjadi verba yang berafiks serta memiliki rujukan pada konteks kalimat yang mendahuluinya dalam TSA. 


\section{Pergeseran Level}

\section{Data 1}

TSU: Harry had seen them at it during his evening walks around Little Whinging...

[Harry melihat mereka di [..] selama perjalanan malamnya di sekitar Little Whining...]

TSA: Harry melihatnya sendiri sewaktu dia berjalan-jalan,

Pada data (1), pergeseran terjadi dari level leksikal ke gramatikal dan bersifat referensial. Padanan it melekat dalam bentuk affiksasi -nya pada verba melihat yang merujuk secara anaforis pada konteks sebelumnya.

\section{Data 2}

TSU: It is you.

\section{$[$ [..] kamu/kau]}

TSA: Kau.

Pada data (2), pergeseran level terjadi dari level gramatikal ke leksikal dan bersifat antisipatory cleft. 'it is you' merupakan 1 unit klausa yang tidak dapat di pisahkan secara gramatikal yang diterjemahkan menjadi 1 leksikal 'Kau' dalam bahasa sasaran.

\section{Pergeseran Kelas}

\section{Data 1}

TSU: It was his pride and joy, a gift from Sirius, an international standard broomstick.

[ [..] adalah kebanggaan dan kesenangannya, sebuah hadiah dari Sirus, ...]

TSA: Sapu itu kebanggan dan kebahagiaannya, hadiah dari Sirius, sapu berstandar internasional.

Pada data (1), kata it merujuk secara anaforis pada 'sapu' di kalimat sebelumnya. Pergeseran kelas terjadi pada kata it di dalam teks sumber yang diterjemahkan menjadi kelas kata yang berbeda yakni nomina sapu di dalam teks sasaran.

\section{Data 2}

TSU : Stop doing it! I'll h-hit you, I swear I will!

[ Berhenti melakukan [..]! ...]

TSA: J-jangan lakukan lagi! K-kupukul kau! 
Pada data (2), kata it sebagai pronomina mengalami pergeseran kelas kata ketika diterjemahkan di dalam bahasa sasaran menjadi adverbia. Kata it di elipsis oleh penerjemah di dalam bahasa sasaran, karena dalam hal ini penerjemah bisa saja menerjemahkan kalimat imperative tersebut menggunakan kata tunjuk 'ini' atau 'itu' ['j-jangan lakukan ini/itu lagi!'] untuk merujuk secara ektoforis pada konteks yang mendahului. Namun, tidak mungkin memilih kata pengacu -nya ['j-jangan lakukannya lagi!'] untuk menggantikan objek rujukan yang di maksud karena akan terbaca tidak natural dan tidak berterima oleh pembaca pada teks sasaran, lagipula konstruksi kalimat seperti ini pun jarang ditemui baik dalam bentuk ujaran maupun tertulis dalam bahasa sasaran, sehingga kemungkinan oleh penerjemah, menghilangkan informasi it dan menambah kata keterangan 'lagi' adalah pilihan yang paling sesuai untuk tetap mempertahankan makna.

\section{Pergeseran Unit}

\section{Data 1}

TSU: Even though his aunt and uncle could not possibly know how bad Harry felt at admitting it.

[ ...., Harry merasakan kepada mengakui [..] ]

TSA: Meskipun bibi dan pamannya tak mungkin tahu betapa berat baginya mengakui hal ini.

Pada data (1), pergeseran unit terjadi dari 1 unit Kata it ke frasa hal ini, dalam data ini kata it bersifat referensial anaforis.

\section{Data 2}

TSU: It's just lucky I put Mr. Tibbies on the case!

[ [..] hanya beruntung ...]

TSA: Untung aku minta Mr. Tibbles mengawasi!

Pada data (2), pergeseran unit terjadi dari 1 unit klausa stative 'It's just lucky' ke kata leksikal 'untung' - dalam hal ini it bersifat Antisipatory Cleft. It tidak memiliki padanan yang tepat di dalam bahasa sasaran, di sisi lain struktur kalimat bahasa sumber yang berbentuk pola S P O berbeda dengan bahasa sasaran yang tidak menonjolkan fungsi S P O, sehingga pergeseran bentuk pun terjadi.

\section{Data 3}

TSU: And it looks like it is going to rain. (Hal.245 Bab.13)

[Dan [..] kelihatannya seperti [..] akan hujan]

TSA: Dan kelihatannya akan hujan. (Hal.371 Bab.13) 
Kata it pada data (3) di atas mengalami subtitusi pada padanannya dalam TSU. Secara gramatikal hasil terjemahannya 'kosong' karena unit konstituen it jelas tidak memiliki padanan pada TSA. Pada tahap ini, penerjemah melakukan penghilangan informasi it pada TSA. Pada akhirnya yang muncul dalam TSA adalah 'Dan kelihatannya akan hujan'. Pergeseran unitpun terjadi dari klausa ke dalam leksikal.

\section{Data 4}

TSU: It was Saturday. (Hal.259 Bab.14)

$$
\text { [ [..] adalah Sabtu] }
$$

TSA: Hari ini hari Sabtu. (Hal.391 Bab 14)

Hal serupa terjadi pada data (4), kata It sebagai kata yang diterjemahkan menjadi frasa nomina 'hari ini', adalah impersonal. 'hari ini' merupakan hasil subtitusi dari padanan terjemahan it yang meskipun secara semantis tidak bermakna dan tidak memiliki rujukan, it difungsikan sebagai subjek yang dibutuhkan sebagai pemenuhan kaidah dalam TSU. Sementara dalam TSA, penerjemah mensubtitusi subjek yang kosong dari TSU dengan frasa nomina 'hari ini' untuk menegaskan 'hari Sabtu', sebab dalam konteks narasi menuliskan 'hari Sabtu' tidak cukup untuk membantu menjelaskan situasi atau latar waktu pada cerita narasi tersebut. Lebih lanjut, dalam bahasa Indonesia, frasa nomina atau frasa kata kerja dapat mengisi fungsi predikat pada kalimat seperti pada TSA sehingga data kalimat pada TSA berpola Subjek-Predikat dan sudah cukup berterima.

Hal ini sangat berbeda pada urutan kata dalam kalmat bahasa Inggris yang mengharuskan persetujuan antara subjek dan kata kerja (dengan penambahan objek) untuk dapat berterima. TSU memiliki struktur yang sedikit kaku dan formal sementara TSA dapat membentuk kalimat secara lebih fleksibel. Pergeseran level memang tidak terjadi dalam kasus ini namun tetap saja terdapat perbedaan relasi gramatikal yang menonjol pada TSA dan TSU sehingga membentuk kesepadanan makna di antara keduanya sangat bergantung pada unsur tekstual dan kontekstual dalam narasi.

Kata it dengan sifat impersonal tidak dapat dipaksakan untuk memiliki rujukan, kehadirannya merupakan faktor utama dalam kaidah gramatikal pada TSU. Pada kasus it sebagai referensial, penerjemah dapat memperoleh rujukan it sebagai padanan terjemahan pada TSA namun kata it yang tidak dapat diprediksi karena sifatnya yang sangat bergantung pada konteks wacana dimana it berada membuat it memiliki makna gramatikal dan tidak memiliki makna leksikal.

Dari pemaparan data di atas dapat di peroleh kesimpulan bahwa pergeseran kelas hanya dapat terjadi pada It sebagai referensial. Dimana kata it dapat disubstitusikan ke kelas lain 
sebagai rujukannya contohnya dalam bentuk frasa nomina, adverbial, .atau adjektiva, dan lain sebagainya. Sedangkan pergeseran struktur hanya terjadi pada it sebagai anticipatory karena struktur TSU tidak dapat diterjemahkan secara secara sejajar pada TSA karena perbedaan sistem struktur antara kedua Bahasa, dalam kasus ini penerjemah melakukan penghilangan kata it pada TSU (omitting).

2. Bentuk-Bentuk Kesepadanan Terjemahan it ke dalam Bahasa Indonesia pada novel Harry Potter and The Order of The Phoenix

Untuk mencapai kesepadanan makna maka perlu untuk melihat kesepadanan secara leksikal. Transformasi leksikal muncul berupa penambahan, penghilangan dan penggantian leksikal (Baker 1992 hal.190-196; Nida, 1964).

\section{a. Penambahan (gain of information)}

Penambahan merujuk pada informasi yang tidak ditemukan dalam TSU namun informasi itu ditambahkan dalam TSA. Nida (1964: 16) berpendapat gain refers to the additional features in TT that does not exist in the ST and implied values in TT 'penambahan mengacu pada fitur tambahan pada TSA yang tidak muncul pada TSU and mempengaruhi makna TSA'. Penambahan muncul sebagai informasi yang berguna pada TSA baik untuk memperkaya maupun untuk memperjelas TSU. Penambahan tidak selalu mucul sebagai penambahan informasi baru pada TSA, sebagian muncul berupa pengulangan informasi lama. Nida (1964; 25) mengelompokan penambahan ke dalam dua bentuk yaitu penambahan yang muncul sebagai informasi untuk TSA dan untuk TSA. Penambahan TSA muncul dalam bentuk penambahan informasi mengenai budaya TSU. Penambahan TSA muncul berupa informasi tambahan yang berfungsi untuk menjelaskan makna kontekstual dari TSU.

Lain halnya dengan penambahan pada strategi struktural, penambahan di sini dilakukan demi kepentingan kejelasan makna. Contohnya pada data [1]:

TSA: "Harry's temporarily stupefied brain seemed to reawaken. Ministry representatives will be calling at your place of residence shortly to destroy your wand. There was only one thing for it" (Penerjemah, hal)

TSU: "Otak Harry yang terbius-sementara tampaknya terbangun lagi. Petugas kementrian sihir akan datang ke tempat tinggal anda tak lama lagi untuk menghancurkan tongkat sihir anda. Hanya ada satu cara untuk menghindarinya" (Bab 1, hal 26)

Pada data di atas, kata it diterjemahkan 'menghindarinya' pada TSA. Suffix -nya yang melekat pada kata kerja 'menghindari' merujuk secara endoforis kepada sebuah keadaan sebelumnya 'Ministry representatives will be calling at your place of residence shortly to destroy your wand', Tidak ada kata ganti yang sepadan untuk menggantikan it di dalam teks sasaran sehingga penerjemah memasukkan informasi tambahan di dalam teks terjemahannya 
karena menurutnya pembaca memang memerlukan informasi tersebut lebih detail. Pilihan kata menghindarinya ini pun adalah bagian dari penambahan pada bentuk strukturnya. Informasi tambahan ini bisa diletakkan di dalam teks untuk memanipulasi padanan yang tidak ada dan atau memperjelas makna dalam kalimat (Newmark, 1988: 91-92).

\section{b. Penghilangan}

Elipsis (penghilangan/pelesapan) adalah proses penghilangan kata atau satuan-satuan kebahasaan lain. Elipsis juga merupakan penggantian unsur kosong (zero), yaitu unsur yang sebenarnya ada tetapi sengaja dihilangkan atau disembunyikan. Tujuan pemakaian elipsis ini salah satunya yakni untuk mendapatkan kepraktisan bahasa agar bahasa yang di sampaikan bisa menjadi singkat, padat, dan jelas serta mudah di mengerti dengan cepat. Sebenarnya sama dengan subtitusi, hanya saja prosesnya berbeda dimana elipsis ini disubtitusi oleh sesuatu yang kosong atau tidak ada.

Data 1

TSU : "W-what are you d-doing? St-stop it!,"

['Apa yang kau lakukan? Hentikan [..] ]

TSA : "Apa yang kau lakukan? hentikan!" (Bab 1, hal 30)

Kata it sebenarnya merupakan kata ganti yang mengganti rentetan peristiwa sebelumnya dan diacu oleh kata it secara ektoforis atau ekstralingual karena rujukannya yang terlalu panjang dan begitu kontekstual.

Pada kalimat di atas yang merupakan potongan percakapan Dudley dan Harry, kata 'hentikan' bisa saja di perjelas dengan keterangan tambahan 'itu' atau 'ini' menjadi 'hentikan itu/ini' sehingga 'ini', 'itu' dapat hadir sebagai kata tunjuk untuk membantu menjelaskan makna yang diacu kepada pembaca, namun penerjemah memilih untuk tidak.

Kata it pada data tersebut merupakan ektoforis yang situasinya di kontekstualkan. Rujukannya tidak tertulis secara tersurat namun dihadirkan melalui konteks yang merujuk pada sebuah rentetan peristiwa yang di ceritakan sebelumnya, sehingga penulis pada TSU menggunakan kata it sebagai kata ganti sedangakan penerjemah memilih untuk melakukan elipsis dalam TSA agar kalimat dengan inti yang mengandung informasi yang sama tidak berulang. Perbedaan lingusitik antar bahasa inilah yang menyebabkan penghilangan hanya dapat diminimalisasir namun tidak mungkin untuk dihindari. Penghilangan yang tidak dapat dihindari ini muncul sebagai akibat dari perbedaan sistem linguistik antar dua bahasa dengan mengesampingkan kemampuan dan kompetensi penerjemah. 


\section{c. Penggantian}

Penggantian merujuk pada perubahan leksikal pada TSU dan TSA. Penggantian dalam penerjemahan dilakukan pada leksikal yang padanannya tidak ditemukan pada TSA. Selain itu penggantian juga muncul sebagai pilihan penerjemah yang seringkali menyebabkan pergeseran pada makna. Berikut tertera dalam contoh data:

1) Penggantian fungsi nominal adalah penggantian terhadap nomina (kata benda) dengan menggunakan unsur penyulih yang maknanya berbeda dari unsur substitusinya.

Bsu: They turned right down the narrow alleyway where Harry had first seen Sirius and which formed a shortcut between Magnolia Crescent and Wisteria Walk. It was empty and much darker than the streets its linked because there were no streetlamps. (Hal.27, Bab 1)

Bsa: Mereka berbelok kanan ke jalan setapak sempit, tempat pertama kali Harry melihat Sirius. Jalan setapak itu membentuk jalan pintas antara Magnolia Crescent dan Wisteria Walk. Jalan itu kosong dan jauh lebih gelap daripada kedua jalan yang dihubungkannya, karena di sana tak ada lampu jalanan.

Kata 'jalan itu' adalah subtitusi dari 'jalan setapak sempit'.

2) Penggantian verbal adalah penggantian terhadap kata kerja dengan menggunakan unsur penyulih yang maknanya berbeda dari unsur substitusinya.

Bsu: "Expecto Patronum!"

His voice sounded dim and distant. . . Another wisp of silver smoke, feebler than the last, drifted from the wand - he couldn't do it anymore, he couldn't work the spell $=\left(\mathrm{Hal}_{3} 32, \mathrm{Bab} 1\right)$

Bsa: "Expecto Patronum!"

Suaranya terdengar samar dan jauh. Kembali terlihat kepulan asap keperakan, lebih lemah daripada sebelumnya, keluar dari tongkat__dia tak bisa melakukannya lagi, dia tak bisa lagi menggunakan mantranya.

Verba 'menggunakan' adalah penggantian dari verba 'melakukan' sesuai konteks narasi.

3) Penggantian klausal adalah penggantian terhadap seluruh kalimat. Substitusi klausal menggantikan seluruh kalimat sebelumnya.

Contoh:

Bsu: How am I going to tell Dumbledore what's happened, I can't Apparate - "'"Oh my dear, I wish it were so but I'm afraid = MUNDUNGUS FLETCHER, I AM GOING TO KILL YOU!" (Hal.39, Bab 2)

Bsu: "Bagaimana caraku memberi tahu Dumbledore apa yang telah terjadi? Aku tak bisa ber-Apparate."

Bsa: "Oh, nak, seandainya saja begitu, tetapi sayangnya... MUNDUNGUS FLETCHER, KUBUNUH KAU!" 
Klausa 'seandainya saja begitu' adalah penggantian kalimat dari "Bagaimana caraku memberi tahu Dumbledore apa yang telah terjadi? Aku tak bisa ber-Apparate."

\section{Ketidaksejajaran}

Ketidaksejajaran bentuk terjadi ketika TSA tidak dapat memenuhi struktur TSU, sehingga informasi dari TSU yang tidak memiliki padanan dalam TSA harus dihilangkan oleh penerjemah atau tidak bisa dipaksakan untuk hadir.

\section{a. Penghilangan (Omitting)}

\section{Data 1}

TSU: Tonks swerved and Harry followed her, watching his trunk swinging wildly beneath her broom. "We need more height. ... Give it another quarter of a mile!" (Hal. 55, bab3)

TSA: Tonks berbelok dan Harry mengikutinya, memandang kopernya bergoyang liar di bawah sapu Tonks. "Kita perlu terbang lebih tinggi... naik empat ratus meter lagi!"

It yang hadir untuk mengekspresikan cuaca, kondisi lingkungan, waktu, jarak seperti yang ditunjukan pada data (1) adalah hampa makna sehingga dalam transformasi terjemahannya, secara grammatikal, kata ganti it tidak diterjemahkan pada TSA disebabkan tidak adanya rujukan pada TSA (Semantis; hampa makna), hadir hanya sebagai pemenuhan kaidah struktur TSU.

Berdasarkan keseluruhan data yang memaparkan klausa dan kalimat yang menggunakan kata it untuk menyatakan cuaca, lingkungan, waktu dan juga jarak menempatkan fungsi it sebagai hampa makna sehingga kata it hilang dalam terjemahannya di dalam teks sasaran. Hal yang paling menonjol yakni usaha penerjemah merubah struktur TSA agar kesepadanan makna dapat tercapai dengan menyesuaikan konteks dalam narasi, misalnya saja penambahan leksikal seperti pada data (1) 'Give it another quarter of a mile', secara literal kemungkinan akan diterjemahkan seperti berikut 'beri yang lain sebuah perempat mil'.

Penerjemahan literal ini akan sangat kaku dan tidak sesuai dengan konteks narasi pada teks sumber. Mungkin ini menjadi salah satu faktor penerjemah memilih menerjemahkannya menjadi 'naik empat ratus meter lagi' yang tentunya setelah memperhatikan secara detail koherensi dan konteks pragmatik dari kalimat sebelum dan sesudahnya.

3. Faktor-Faktor Penyebab Terjadinya Pergesaran Padanan Terjemahan it ke dalam Bahasa Indonesia pada novel Harry Potter and The Order of The Phoenix

Baker (1992) sendiri membagi faktor-faktor yang dapat menyebabkan atau menjadi bagian dari ketidaksepadanan teks sumber terhadap teks sasaran, yakni, a. ketika terjemahan berbicara mengenai konsep budaya khusus atau kata-kata/istilah budaya, b. konsep bahasa sumber tidak 
tersedia dalam bahasa sasaran, c. konsep bahasa sumber secara semantik sangat kompleks, d. perbedaan persepsi terhadap suatu konsep, e. bahasa sasaran tidak mempunyai unsur atasan (superordinat), f. bahasa sasaran tidak mempunyai unsur bawahan atau kata khusus (hiponim), g. perbedaan dalam perspektif interpersonal dan fisik, h. perbedaan dalam hal makna ekspresif, i. perbedaan bentuk kata, j. perbedaan dalam hal tujuan dan tingkat penggunaan bentuk-bentuk tertentu, k. padanan di atas tataran kata (contohnya, padanan kolokasi), padanan grammatikal. Berikut merupakan beberapa faktor yang paling menonjol menyebabkan terjadinya pergeseran gramatikal padanan terjemahan it pada teks sasaran sehingga ketidaksejajaran bentuk tidak dapat dihindari.

a. Di dalam kaidah grammatikal bahasa Inggris, fungsi struktur sangat di tonjolkan sehingga ketika tidak ada yang dapat menggantikan sebuah fungsi dalam struktur kalimat tertentu maka it akan hadir untuk mengisi fungsi tersebut sebagai subjek di dalamnya (menjadikan kata it ini harus ada, mengingat tidak ada kata lain yang dapat menggantikan fungsi atau kedudukannya dalam tataran grammatikal bahasa sumber), sementara bahasa Indonesia tidak menonjolkan fungsi dalam konstruksi kalimatnya, tidak memprioritaskan kehadiran subjek atau tidak mengutamakan pola urutan subjek-predikat-objek yang runtun dan lengkap.

b. Dalam konstruksi kalimatnya, it dapat befungsi sebagai subjek dan objek. Apabila memiliki rujukan, maka kata it akan bersifat sebagai referent atau kata ganti yang memiliki anteseden atau acuan baik pada teks sumber maupun teks sasaran, Kata ganti it hadir sebagai upaya untuk mengefektifkan kalimat dalam wacana yang cukup panjang agar subjek atau objek tertentu yang sama tidak berulang-ulang di sampaikan dalam teks.

c. Bahasa Indonesia mempunyai unsur atasan (superordinat), dan unsur bawahan atau kata khusus (hiponim), hanya saja tidak begitu spesifik secara literal menggambarkan konsep it sendiri sesuai bahasa sumber. Di dalam bahasa Indonesia terdapat padanan kata it misalnya [ini, itu, dia, begini, begitu, nomina yang diacu], seperti data hasil yang telah dipaparkan pada analisis sebelumnya, namun padanan tersebut tidak jelas bentuknya atau belum cukup menjelaskan sesuatu atau nomina tertentu yang dimaksudkan untuk di jadikan acuan secara eksplisit. Sementara di dalam bahasa Inggris 'bentuk yang tidak jelas' tersebut dapat disampaikan dengan kata it. Hal ini menunjukan perbedaan konsep yang sangat jauh antara it dan konsep padanannya di dalam bahasa Indonesia. 


\section{KESIMPULAN}

Dari pemaparan data di atas dapat di peroleh kesimpulan bahwa pergeseran kelas hanya dapat terjadi pada It sebagai referensial, it dapat disubstitusikan ke kelas lain sebagai rujukannya contohnya dalam bentuk frasa nomina, adverbial, atau adjektiva, dan lain sebagainya. Sedangkan pergeseran struktur hanya terjadi pada it sebagai anticipatory dan atau impersonal karena struktur TSU tidak dapat diterjemahkan secara sejajar pada TSA karena perbedaan sistem struktur antara kedua Bahasa, dalam kasus ini penerjemah melakukan penghilangan kata it pada TSU (omitting). Perbedaan antara tipe pergeseran struktur dan intra sistem adalah, pergeseran struktur terjadi akibat perbedaan struktur yang mengakibatkan penerjemahan klausa/ kalimat tidak dapat dipaksakan menjadi bentuk yang sejajar, sedangkan, pergeseran intra sistem pada dasarnya masih dapat diterjemahkan secara sejajar, namun, penerjemah memilih bentuk/struktur yang berbeda karena alasan efektivitas klausa/kalimat atau penonjolan informasi tertentu, sehingga terkadang struktur TSU mengalami penghilangan (elipsis) sebagian atau perubahan pada TSA. Perbedaan bentuk ini mengakibatkan pergeseran padanan terjemahan it sebagai akibat dari transformasi gramatikal dapat berupa perbedaan tipologi antara TSU dan TSA, fitur-fitur relasi gramatikal yang berbeda misalnya konsep tenses yang tidak sama dengan konsep TSA yang menggunakan leksikal sebagai konsep kala dalam kalimat.

\section{DAFTAR PUSTAKA}

Anggraini, V. (2009). "Penanda Kohesi Substitusi pada Novel Sang Pemimpin Karya Andrea Hirata". Skripsi. Surakarta. FKIP: Universitas Muhammadiyah Surakarta

Alwi, H, et al. (1998). Tata Bahasa Baku Bahasa Indonesia. Jakarta: Balai Pustaka.

Arifin, Z, Juniah H.M. (2008). Sintaksis Bahasa Indonesia. Jakarta: Grasindo.

Baker, (1992). In other Words: A Course Book on Translation. London: Sage Publication Ltd.

Crystal, D. (1988) A Dictionary of linguistics and Phonetics. Oxford: Oxford Unversity press. File : IA/ htm. Miss Fidditch, 2005.

Chaer, A. (2011). Tata Bahasa Praktis Bahasa Indonesia. Jakarta: RinekaCipta.

Chaer, A. (2009). Sintaksis Bahasa Indonesia (Pendekatan Proses). Jakarta: Rineka Cipta.

Hatim and Munday. (2004). Translation an Advanced Resource Book. New York: British Library Cataloguing

Hoed, B. H. (2006) Penerjemahan dan Kebudayaan. Jakarta: Pustaka Jaya

Halliday, M.A.K and Hassan, R. (1976) Cohesion in English, London, Longman

J.C Catford. (1965). A Linguistics Theory of Translation, Oxford: Oxford University Press.

Hatim, B. (2001). Teaching and researching translation. Beijing: Foreign Language and Research Press.

Hatim, B. \& Munday, J. (2004). Translation: An advanced resource book. London and New York: Routledge. [4] Keegan, S. (2009). Qualitative research. London. 
Hewings, Martin \& Hewings, Ann. (2002). "It is interesting to note that...": A comparative study of anticipatory 'it' in student and published writing. English for Specific Purposes. 21. 367-383. 10.1016/So889-4906(01)00016-3.

J. Brill. Sapir, E. (1921). Language. New York: Harcourt Brace Jovanovich.

K. Venuti, L. (2000). The translation studies reader. London and New York: Routledge.

Keraf, G. (1990).Tata Bahasa Rujukan Bahasa Indonesia. Jakarta: Grasindo.

Kridalaksana, Hi, et al. (1999). Tata Wacana Descriptif Bahasa Indonesia. Jakarta : Fakultas Sastra Universitas Indonesia.

Kristanto. (2000). "Kekohesifan dalam Majemuk Setara dalam Bahasalndonesia". Skripsi. Yogyakarta: Universitas Gadjah Mada.

Kuncoro, R. S. (2011). "Aspek Gramatikal Referensi dan Leksikal padaLirik Lagu Grup Band Ungu dalam Album Religi "Aku dan Tuhanku".Skripsi. Surakarta. FKIP: Universitas Muhammadiyah Surakarta

Larson, M. L. (1998). Meaning based translation a guide to cross language equivalence. London: University Press of America, Inc.

Lyons, y. (1968) A study of English Language

Levinson, S. C. (1983). Pragmatics: Cambridge, England: Cambridge University Press

Lingga, H. D. dan Utomo. (2003). Intisari Tata Bahasa Inggris Kontemporer. Bekasi: Kesaint Blanc.

Machali, R. (2000). Pedoman bagi Penerjemah. Jakarta: PT.Grasindo.

Mahsun. (2007).Metodologi Penelitian Bahasa: Tahapan Strategi, Metode, dan Tekniknya. Jakarta: PT. Raja Grasindo Persada.

Mahsun. (2005). Metode Penelitian Bahasa. Jakarta: Rajawali Pers.

Moentaha, dan Salihen. (2008). Bahasa dan Terjemahan, Jakarta: Kesaint Blanc.

Munday, J., (2001). Introducing translation studies: Theories and applications. London: Routledge.

Nida, E. A. dan Ch.Taber. (1974). The Theory and Practice of Translation. Leidin; E.J Brill

Newmark, P. (1991). About Translation. UK: Multilingusl Matters.

Newmark, P. (1981). Approach to Translation. Oxford: Pergemon Press.

Prakrasa, I. B. (2007).Analisis Kalimat (fungsi kategori, peran). Jakarta: Rineka Cipta.

Pinchuck, I. (1977). Scientific and Technical Translation. London: Andre Deutsch.

Rokhamah. (2008). Menjelaskan Diskripsi Frase Sebagai Gabungan Dua Kata Atau Lebih. Skripsi S1. Surakarta: UMS

Sudaryanto. (1993). Metode Dan Aneka Teknik Analisis Bahasa.Yogyakarta: Duta Wacana University prees.

Sukini. (2010). Sintaksis Sebuah Panduan Praktis, Surakarta: Yuma Pustaka.

Teeuw, A, (1989). Sastra dan Ilmu Sastra; Pengantar Teori Sastra; Jakarta: Pustaka

Jaya

Tarigan, Henry Guntur. (2009). Pengajaran Sintaksis. Bandung: Angkasa.

Tarigan, Henry Guntur. (2009). Prinsip-prinsip Dasar Sintaksis. Bandung: Angkasa. 
Yule, G. (1996). Pragmatics. Oxford: Oxford University Press

Bas Aarts, Sylvia Chalker, Edmund Weiner (2014), 'sort through more grammatical "it" details in "The Oxford Dictionary of English Grammar', Oxford.

Gerald C. Nelson, Sidney Greenbaum (2013), 'Nominal clauses in "An Introduction to English Grammar."

Fern L. Johnson (2000), 'Speaking Culturally: Language Diversity in the United States.' Sage, 2000

Rodney D. Huddleston, Geoffrey K. Pullum (2005), 'A Student's Introduction to English Grammar', Cambridge University Press, 2005

James D. McCawley (1998), 'The Syntactic Phenomena of English', 2nd ed. University of Chicago Press, 1998)

Christopher J. Hall (2005), 'An Introduction to Language and Linguistics: Breaking the Language Spell'. Continuum, 2005 Publishing. 